\title{
NOTES
}

\section{RESTRAINT AND COERCION: EXECUTION OF A COLLECTIVE BARGAINING CONTRACT BY A MINORITY UNION}

THE National Labor Relations Board has recently held that a union
commits an unfair labor practice by the simple act of signing a collective
bargaining contract by which it is recognized as exclusive bargaining
agent at a time when the union does not represent a majority of the
employees affected by the agreement. This result follows even if the
union believes in good faith that it does represent a majority of the
employees.

In Bernard-Altmann Texas Corporation, ${ }^{1}$ a local of the International Ladies Garment Workers Union had been trying unsuccessfully ${ }^{2}$ for ten months to organize a small knitting firm in San Antonio, Texas. In August 1957, the union and the employer executed a "memorandum of understanding" recognizing the union as exclusive bargaining agent for a unit of production and shipping employees. At the time of signing, the union held 158 authorization cards from a bargaining unit which the union believed to contain a total of 286 einployees. It was later discovered that this total was incorrect ${ }^{3}$ and that the union did not in fact hold cards from a majority of the employees in the unit. The Board, while assuming that the union entertained a good faith belief in its majority status, nevertheless held that by signing the contract the union coinmitted an act of unlawful restraint and coercion within the meaning of section $8(\mathrm{~b})(\mathrm{I})(\mathrm{A})$. $^{4}$

\footnotetext{
1122 N.L.R.B. No. 142 (1959).

${ }^{2}$ In July 1957, some of the employees walked off the job to protest a wage reduction. It appears that the union did not conduct the strike; it was a spontaneous protest by a number of workers against the wage policies of the employer. The union continued its organizational efforts during the strike.

${ }^{3}$ The mistake was due to the great number of layoffs in the seasonal garment industry. In its determination of the total number of employees in the unit, the union failed to include 120 shipping and production employees who had been temporarily laid-off. Only 88 of the 120 emplojees had signed union authorization cards. Consequently, the union held either 158 authorization cards out of a total of 406 employees - or held 70 authorization cards out of a total of 286 . In either view, the union did not have a inajority.

" "Section 8. .... (b) : It shall be an unfair labor practice for a labor organization or its agents .... (I) to restrain or coerce ... (A) employees in the exercise of the
} 
Prior to 1957 , the Board's findings of "restraint and coercion" under this section had been limited to cases involving the harsher forms of oppressive tactics, including economic reprisals, physical violence, intimidation, and deliberate deception by the union in conducting organizational activity. ${ }^{5}$ Curtis Brothers, Inc., ${ }^{6}$ the first decision to depart from the pattern of narrow interpretation, held that otherwise lawful union activity with an unlawful objective constitutes unlawful restraint and coercion under section $8(b)(I)(A)$. The objective deemed unlawful in that case was a demand that the employer sign a contract recognizing the minority union's conducting the picketing as exclusive bargaining agent. ${ }^{7}$

In as much as the Curtis Brothers case has been reversed, ${ }^{8}$ the legal status of the instant decision is at least questionable. ${ }^{9}$ If the former decision is truly defunct, ${ }^{10}$ and it is lawful for a minority union to picket peacefully for recognition, it might not be unlawful for the minority union to effectuate the purpose of such lawful, peaceful picketing by signing a contract recognizing it as the exclusive bargaining agent.

Closer analysis, however, reveals that the Curtis Brothers and

rights guaranteed in section 7." Section 7 provides that "Employees shall have the right ... to bargain collectively through representatives of their own choosing, and ... shall also have the right to refrain from any or all such activities except" when subject to a union shop agreement authorized by section 8(a) (3). Labor Management Relations Act (Taft-Hartley Act) $\S 8(\mathrm{~b})(\mathrm{I})(\mathrm{A}), 49$ Stat. 449, 452 (1935), as amended 61 Stat. 136, 140 (1947), 29 U.S.C. $\$ \S 157,158(a)$ (1) (1952).

${ }^{5}$ Former Member Murdock referred to the Board's previous findings on $\S 8(\mathrm{~b})(\mathrm{x})$ (A) in his dissent in Curtis Brothers, Inc., IIg N.L.R.B. 232, 26I (I957): "In these cases the Board found that section $8(\mathrm{~b})(\mathrm{I})(\mathrm{A})$ covers violence and intimidation by unions and threats of economic action against specific individuals and is directed at themeans by which strikes and picketing are conducted, not the object of such activities." Professor Archibald Cox has surveyed the cases in this area and has reached the sameconclusion. See editorial comments, Cox, Labor Laws: Cases aNd Materiats 333-3T (4th ed. 1958).

119 N.L.R.B. 232 (1957).

${ }^{7}$ Recognition of a union in these circumstances would constitute unlawful interference, restraint, and coercion under section $8(a)(x)$, and unlawful assistance to the union under section 8(b) (a). International Metal Prods. Co., 104 N.L.R.B. 1076. (1953).

${ }^{8}$ Drivers Union, Local 639 v. NLRB (D.C. Cir.) 43 L.R.R.M. 2156 (1958).

${ }^{\circ}$ Although the majority denied that it was relying in whole or in part on the Curtis case, the instant decision has been characterized as merely an extension of the discredited Curtis doctrine by Member Fanning in his dissenting opinion.

${ }^{10}$ Unless the Board recants or the Supreme Court agrees with the Court of Appeals. for the District of Columbia, a reversal by the latter court will not be effective outsidethe District of Columbia. The Supreme Court has granted certiorari. 27 U.S.L. WEEK 3293 (U.S. April 20, 1959) (No. 40). 
Bernard-Altmann decisions are concerned with basically different issues. In the Curtis Brothers case, the Board decided that a union could not lawfully picket for recognition where the granting of the recognition would be an illegal act on the part of the employer. ${ }^{11}$ The issue in Bernard-Altmann, on the other hand, was whether the union's mere participation in an act illegal for the employer should, for this reason alone, also be illegal for the union. Still another fundamental distinction between the two decisions is the nature of the coercion involved. While the Curtis Brothers case was concerned with the indirect economic effect upon employees of a picketed employer, the union in Bernard-Altmann completely pre-empted the employees' choice of representatives.

Thus, on two bases, it would appear that the question of whether picketing for recognition by a minority union is lawful or unlawful may be distinguished from the question of whether the minority union is guilty of restraint and coercion if it goes one step further and signs a contract with the employer.

As a background for consideration of the practical implications of the instant decision, it should be noted that the legislative history ${ }^{12}$ of section $8(\mathrm{~b})(\mathrm{I})(\mathrm{A})$ leaves considerable doubt whether Congress ever intended "restraint and coercion" to include such peaceful acts as de facto representation by a minority union. In the final analysis, however, the question whether de facto representation by a minority union actually amounts to coercion and restraint of employees in the exercise of their section 7 rights must be determined from a consideration of the practical effects of such representation. The most obvious effect is that the minority union will be able to negotiate for contract terms establishing wages, hours, and working conditions ${ }^{13}$ for all employees in the

\footnotetext{
${ }^{11}$ See note 7 supra.

${ }^{12}$ Dissenting Member Fanning's consideration of statements made in speeches and during congressional debate by Senators Taft and Ball, two prominent sponsors of the Taft-Hartley amendments, led bim to the conclusion that the language "restraint and coercion" in section $8(\mathrm{~b})(\mathrm{r})(\mathrm{A})$ was intended to outlaw only such flagrantly abusive tactics as "goon squads," threats of physical violence and economic pressure directed at individual employees or definite groups of employees. 93 CoNG. REc. 4435-36, A 2252 (1947). Read in context, however, it is clear that the examples cited in floor debate were intended to be merely representative and not exclusive. See further statements of Sénator Taft, 93 Cong. REC. 4435-36 (1947).

${ }^{18}$ The union's contract with Bernard-Altmann did not include a union shop clause. Dissenting Member Fanning stated that the absence of such a contract term was significant in his finding that there had been no restraint or coercion of employees' freedom of choice, thus indicating that had such a clause been in the contract his evaluation of its effects unight have been different.
} 
bargaining unit. But evaluation of the true coercive effect of a minority union's assumption of the position of bargaining representative cannot accurately be made without consideration of the several remedies available to employees, by means of which a minority union may be deprived of representative status.

Aside from resorting to self-help through legitimate collective action, any employee ${ }^{14}$ aggrieved by the situation may file unfair labor practice charges with the NLRB alleging violations of sections $8(a)(I)$ and $8(a)(2)$ on the part of the employer. Upon a finding of an unfair labor practice, the NLRB would issue a "cease and desist" order directing the employer to refrain from recognizing the union. ${ }^{15}$ Should a substantial number of the employees desire a different union as its representative, that rival union or any other employee may petition the NLRB for a representation election upon a showing that thirty per cent of the employees in the bargaining unit desire such an election. ${ }^{16}$ This remedy, however, is limited by the contract-bar rule which generally prevents a rival union from obtaining an election within two years after the signing of the collective bargaining contract. ${ }^{17}$ Furthermore, subject to the contract-bar rules, decertification procedures could be utilized to establish officially the minority status of the union currently being recognized by the employer. ${ }^{18}$ The only additional remedy which the instant decision adds to the employees' arsenal of defenses is the power to file an unfair labor practice charge under section $8(\mathrm{~b})(\mathrm{I})(\mathrm{A})$-a power which already is available under sections $8(a)(1)$ and 8(a)(2), though these latter sections are directed at the employer and not the union. ${ }^{19}$ In any event, the sanctions of the Board would be invoked to

\footnotetext{
${ }^{24}$ The National Labor Relations Board Statements of Procedure, \#II I0.02, authorizes any person to file an unfair labor practice charge. 29 C.F.R. § 101.2 (Supp. 1959).

${ }^{15}$ Labor Management Relations Act (Taft-Hartley Act), § ro(c), 49 Stat. 449, 453 (1935), as amended, 61 Stat. 136,146 (1947), 29 U.S.C. § I6o(c) (1952); 22 N.L.R.B. ANN. REP. 62 (1957).

${ }_{29}$ C.F.R. § $101.17-18$ (Supp. 1959).

${ }^{27}$ The Board's contract-bar doctrime would not prevent an election upon petition by a rival union if the agreement signed were a bare recognition agreement not containing substantial terms and conditions of employment. Appalachian Shale Prods. Co., 121 N.L.R:B. No. 149 (1958).

${ }^{18}$ Labor Management Relations Act (Taft-Hartley Act) $\S g(\mathrm{c})(\mathrm{I})(\mathrm{A})(\mathrm{ii}), 49$ Stat. 449; 453 (1935), as amended, 61 Stat. 136, 143 (1947), 29 U.S.C. § 159(c) (I) (a) (ii) (1952). The National Labor Relations Board Statements of Procedure, Series 7 , authorizes any employee to file a petition for such an election. 29 C.F.R. § 101.17 (Supp. 1959):

$\therefore$ It It must be recognized that, from the employer's point of view, a determination that the union was also guilty of an .unfair labor practice would be desirable for the
} 
end representation by and recognition of the minority union. In view of these remedies available to the employees, by which their right to free choice of bargaining representatives can be vindicated, it would seem that de facto representation by a minority union is not the drastic type of compulsion which should fall within "restraint and coercion," but is an act of a type generally, and more properly, denominated "interference."

This decision also involves federal labor policy considerations which indicate that a different rule might be more desirable. It seems fair to say that the decision could have the effect of discouraging the signing of collective bargaining contracts because it requires that a union act therein at its peril, good faith being expressly excluded as a defense. A union may be faced with serious difficulty in ascertaining the exact number of employees in a bargaining unit. This certainly would be true in highly seasonal and cyclical industries in which large scale layoffs are common. ${ }^{20}$ Hence, at any given moment the exact number of employees may be in doubt or may be reasonably, but mistakenly, ascertained. Furthermore, should the employer be negligent in supplying the union with the correct number of employees in a bargaining unit from the payroll records, the union, under the cule of the instant decision, must share the risk of committing an unfair labor practice.

All of these considerations may discourage ${ }^{21}$ unions from signing collective bargaining contracts because none of these circumstances would be considered a legitimate defense and because the necessity for making a determination of majority status would cause delay at the most critical point in negotiations-just prior to signing. Even though the Taft-Hartley Act has retreated from the Wagner Act position of vigorously encouraging the formation of collective bargaining contracts, there is still a very strong national policy favoring industrial stability

reason that it would foreclose adverse publicity emphasizing only the employer's culpability.

${ }^{20}$ Technically, laid-off workers are still employees, but some of them may have obtained permanent equivalent employment elsewhere, in which case they would no longer be so regarded. American Cyanamid Co., I9 N.L.R.B. 1026 (1940).

${ }^{21}$ The deterrent effect of the decision is two-fold. In Bernard-Altmam, the Board's order directed the union to cease acting as bargaining representative until it had demonstrated its majority status in a Board-conducted election. This is a prerequisite not otherwise mandatory which the union might very well desire to avoid because of the delay involved, and because of the ever present possibility of losing the election, which would foreelose additional elections for at least one year. Furthermore, a finding of unfair labor practice by the union would create a psychological atmosphere unfavorable to furtherance of the union's organizational activities. 
which is enhanced by the signing of such contracts. ${ }^{22}$ Discouragement of collective bargaining contracts is obviously not consonant with national labor policy. It would be unfortunate if Bernard-Altmann should have that undesirable effect.

\footnotetext{
${ }^{29}$ It was the conflict between the two fundamental policies favoring a stabilized bargaining relationship and freedom of choice of bargaining representatives that gave rise to the contract bar doctrine.
} 